\title{
リグニン由来エポキシ樹脂の硬化挙動
}

\author{
東京農工大学工学府 長谷川雄紀・敷中一洋・重原淳孝 \\ 東京農工大学生物システム応用化学府 梶田真也 \\ 長岡技術科学大学 政井英司 \\ 日本大学 片山義博 \\ (独) 理化学研究所 中尾愛子 \\ (独) 森林総合研究所 大塚祐一郎・中村雅哉・大原誠資
}

\section{Curing Kinetics of Lignin-based Epoxy Resins}

\author{
Yuki Hasegawa ${ }^{* 1}$, Kazuhiro Shikinaka ${ }^{* 1}$, Shinya Kajita ${ }^{* 2}$, Eiji Masai ${ }^{* 3}$, Yoshihiro Katayama ${ }^{* 4}$, \\ Aiko Nakao ${ }^{* 5}$, Yuichiro Otsuka ${ }^{* 6}$, Masaya Nakamura ${ }^{* 6}$, Seiji Ohara ${ }^{* 6}$, and Kiyotaka Shigehara ${ }^{* 1}$ \\ ${ }^{* 1}$ Graduate School of Engineering and ${ }^{* 2}$ Graduate School of Bio-Applications and Systems Engineering, \\ Tokyo University of Agriculture and Technology, \\ 2-24-16, Naka-cho, Koganei, Tokyo 184-8588, Japan \\ ${ }^{* 3}$ Department of Bioengineering, Nagaoka University of Technology, 1603-1, Kamitomiokamachi, \\ Nagaoka, Niigata 940-2188, Japan \\ ${ }^{* 4}$ College of Bioresource Sciences, Nihon University, 1866, Kameino, Fujisawa, Kanagawa 252-0880, Japan \\ *5 Advanced Science Institute, RIKEN, 2-1, Hirosawa, Wako, Saitama 351-0198, Japan \\ ${ }^{* 6}$ Forestry and Forest Products Research Institute, 1, Matsunosato, Tsukuba, Ibaraki, 305-8687, Japan
}

\begin{abstract}
Curing kinetics of an epoxy resin containing 2-pyrone-4,6-dicarboxylic acid (PDC) nuclei which is obtained from lignin biodegradation intermediates was studied. Activation energy of the resin was estimated according to Kissinger and Ozawa methods. From Kamal equation, reaction constants and reaction rates were calculated. These constants were approximately coincident to those estimated from the results of in situ FT-IR measurement.
\end{abstract}

(Received 31 October, 2011; Accepted 20 December, 2011)

\section{1. 緒 言}

化石資源依存からの脱却と持続可能な社会の実現のた め, バイオマス資源の有効利用が強く望まれている[1-10]. 木質バイオマスの拉よそ $30 \%$ を占めるリグニンは，イソ プロペニルフェノールが酸化重合・ラジカルカップリン グを繰り返した構成要素からなる, 複雑な三次元架橋構 造を有する [4]. セルロースが単一モノマーのグルコース に分解でき, バイオエタノールやポリ乳酸の原料として 有用である 5 -8 $]$ のに対し, リグニンの有効な利用法は確 立されていない $[9,10]$. 著者らは爆砕処理等により得られ たリグニン低分子化物に微生物を作用させ, その代謝中 間体である 2-pyrone-4,6-dicarboxylic acid(PDC) [11]を単一 化合物として得る手法を確立した[12]．PDC は剛直な擬 芳香族骨格を持つので, ベンゼン環化合物を代替できる 可能性がある. したがって, 従来の植物由来プラスチッ クに比べて機械的強度を必要とされる材料, たとえば輸 送機械や建築物などの構造材への応用が期待できる。こ
れまでに我々はPDCがポリエステルやポリアミド, ポリ ウレタンなどの沉用樹脂に応用可能であることを示して きた[13-16]. 特にPDCをエポキシ接着剤に利用した場合, 従来のビスフェノール A 型の樹脂よりも速く, そして強 固に金属を接着する[17]. しかし, その反応速度は定量 的に求められていない. また, 速く・強固な接着を発現 する条件やメカニズムについても詳細な検討は行なわれ ていない. そこで本報告では, エポキシ樹脂の物性評価 に一般に用いられる硬化反応解析手法を用いて PDCエポ キシ樹脂の硬化反応の定量化と, ベンゼン環を持つエポ キシ樹脂との比較により PDC 樹脂の優位性を見出すこと, およびESCA(Electron Spectroscopy for Chemical Analysis) 測定により, PDCエポキシ樹脂と金属との界面結合によ る結合エネルギー変化を確かめることの 2 点を目的とし, 研究を行った. 
<smiles>O=C(OCC1CO1)c1cc(C(=O)OCC2CO2)oc(=O)c1</smiles>

(b)<smiles>O=C(OCC1CO1)c1cccc(C(=O)OCC2CO2)c1</smiles>

(e)<smiles>CC1CCC2C(=O)OC(=O)C2C1</smiles>

(c)

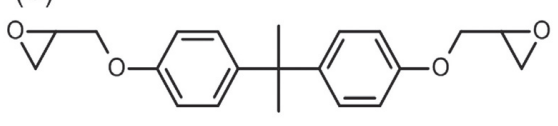

Fig. 1 Chemical structures of materials. (a) DGPDC, (b) DGIPA, and (c) DGEBA ; epoxy monomer. (d) MHHPA; curing agent. (e) BDMA; initiator.

\section{2. 実 験}

\section{1 材料}

PDC を除くすべての材料は, 関東化学(㑣), 和光純薬工 業(侏)，東京化成工業(侏，キシダ化学(株)より購入したもの をそのまま用いた．PDC は既報［12］を元にバニリン酸ま たはプロトカテキュ酸より, Sphingomonas paucimobilis SYK-6 株の代謝経路を利用する方法で合成, 精製したも のを乾燥して用いた. PDC由来のエポキシモノマー, PDC diglycidyl ester, DGPDC[Fig. 1(a)]は, 前報[17]の通り, 脱 水縮合剂 $N, N^{\prime}$-ジイソプロピルカルボジイミドを用いた PDC とグリシドールとのエステル化で合成, メタノール から再結晶精製して用いた。 ベンゼン環を中心骨格に持 つエポキシモノマー, diglycidyl isophthalate, DGIPA[Fig. 1(b)]は，イソフタル酸ジクロリドとグリシドールとのエ ステル化により得た粗生成物を, カラムクロマトグラ フィー(展開溶媒 ヘキサン: 酢酸エチル = 1:1)で精製し て使用した。 ビスフェノール A 型のエポキシモノマーに は市販の Bisphenol-A diglycidyl ether, DGEBA[Fig. 1(c)]を 用いた，硬化剂には，4-メチルヘキサヒドロフタル酸無水 物 [MHHPA，Fig. 1(d)]を，開始剂には 3 級アミンの $N, N$ ジメチルベンジルアミン [BDMA，Fig. 1(e)]をそれぞれ用 いた。

\section{2 エポキシ樹脂組成物調製}

エポキシモノマー $0.25 \mathrm{~g}$ とエポキシ基比 0.85 当量の硬 化剂 MHHPA を， $60^{\circ} \mathrm{C}$ に加熱しながらサンプル管中で電 磁攪拌し, 均一に溶融混合した. その後, 開始剂の BDMA

Table 1 Peak top temperatures of each epoxy resins measured from DSC.

\begin{tabular}{c|c|c|c}
\hline \hline $\begin{array}{c}\text { Heating Rate } \\
{\left[{ }^{\circ} \mathrm{C} / \mathrm{min}\right]}\end{array}$ & \multicolumn{3}{|c}{$T_{\mathrm{p}} /{ }^{\circ} \mathrm{C}$} \\
\hline 5 & DGPDC & DGIPA & DGEBA \\
\hline 10 & 109.0 & 116.7 & 122.2 \\
20 & 121.3 & 130.2 & 134.4 \\
40 & 136.0 & 147.1 & 149.2 \\
& 146.3 & 162.7 & 165.6 \\
\hline
\end{tabular}

をエポキシ基比で 0.02 当量加えて攪拌し, エポキシ樹脂 組成物を調製した。

\section{3 熱分析}

加熱硬化反応の分析は，(株リガク製 Thermo plus DSC 8230 を用いた示差走查熱量測定(DSC)によって行った. アルミパン上に約 $10 \mathrm{mg}$ のエポキシ樹脂組成物サンプルを 載せて $50 \mathrm{~mL} / \mathrm{min}$ の窒素ガスフロー下測定した。測定方法 は「昇温加熱測定」を選択し, 測定温度は, $20^{\circ} \mathrm{C} / \mathrm{min}$ で $-100^{\circ} \mathrm{C}$ まで冷却した後， $5,10,20,40^{\circ} \mathrm{C} / \mathrm{min}$ の昇温速 度で $200^{\circ} \mathrm{C}$ まで加熱した。

\subsection{ESCA スペクトル測定}

鉄粉 $(99.9 \% ， \sim 45 \mu \mathrm{m}) 2.0 \mathrm{~g}$ と，2.2 に記載した組成の DGPDC または DGEBA エポキシ樹脂 $1.0 \mathrm{~g}$ とをよく混合し， 得られたねずみ色の粘性液体を $20 \mathrm{~mm} \varphi$ の $\mathrm{KBr}$ ディスク 上で大まかに薄板状にまとめ, $130^{\circ} \mathrm{C}$ で 30 分間硬化反応 させた．その後 $\mathrm{KBr}$ ディスクを大量の蒸留水中で溶出し， 硬化層が鉄粉表面を薄く覆ったサンプルを調製した。 ESCALAB250[サーモフィッシャーサイエンス侏］により， モノクロ X線源 $(\mathrm{AlK} \alpha, 15 \mathrm{kV}, 150 \mathrm{~W}, 500 \mu \mathrm{m})$ を用い, $2 \times 10^{-8} \mathrm{~Pa}$ の真空下で Fe $2 \mathrm{p}$ スペクトルを測定した.

\section{3. 結果と考察}

\section{1 活性化エネルギー評価}

昇温 (非等温) 測定による活性化エネルギー算出につい ては, 多数の報告がある[18-28]. 今回は Kissinger の式と Ozawaの式を用い，エネルギー算出を行った，具体的に は, DSC の昇温速度と発熱ピーク温度をパラメー夕に3 種類のエポキシ組成物それぞれについて活性化エネル ギーを算出した。

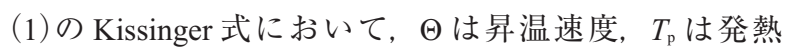
ピーク温度， $E_{\mathrm{A}}$ は活性化エネルギー, $R$ は気体定数であ る. $1 / T_{\mathrm{p}}$ を横軸に, $\ln \left(\Theta / T_{\mathrm{p}}^{2}\right)$ を縦軸にしたプロットの傾き から， $E_{\mathrm{A}}$ が求められる.

$$
\Delta\left(\ln \left(\Theta / T_{\mathrm{p}}^{2}\right)\right) / \Delta\left(1 / T_{\mathrm{p}}\right)=-E_{\mathrm{A}} / R
$$

(2)の Ozawa 式(パラメータの意味は前述のとおり)では,

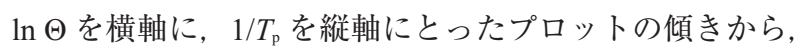

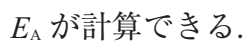

$$
\Delta\left(1 / T_{\mathrm{p}}\right) / \Delta(\ln \Theta)=-R /\left(1052 \cdot E_{\mathrm{A}}\right)
$$

DSC の測定結果から得られた昇温速度と発熱ピーク温 度の関係を Table 1 に示す。ここから, 発熱ピーク温度は DGPDC 樹脂が一番低く, 次いで DGIPA, DGEBA の順と なることがわかる．本結果を式(1)，(2)に代入し得られ た值のプロットを Fig. 2 に示す. Kissinger・Ozawa のそれ ぞれの方法でよく線形近似できていることがわかる．今 回用いたエポキシ組成物すべてについて同様の結果が得 
られたため, プロットの傾きより活性化エネルギーを算 出した (Table 2). Ozawa 式で導出される活性化エネルギー は若干高めになっているが, これは一般的な傾向である [22-25]. この結果より, 活性化エネルギーは高い順に DGPDC $>$ DGEBA $>$ DGIPA となった. 前報[17]において, 他の樹脂に比べ DGPDC 樹脂は速く硬化することが実験 的に明らかとなっている。通常, 活性化エネルギーが小 さいほど反応速度が大きくなり, 本計算結果とは相反す ると考えられる。ここで, 式(2)では昇温速度の増加に対 してピーク温度の変化が小さければ「活性化エネルギー が大きい」とみなされる。このとき, 通常は低昇温速度 で発熱ピーク温度の高温シフトが見られる。これは,「活 性化エネルギーが大きい」=「低温での反応障壁が大きい」 とみなされるからである.一方, Table 1 を見ると, DGPDC 樹脂では大きな昇温速度のとき発熱ピーク温度の低温シ

(a) Kissinger

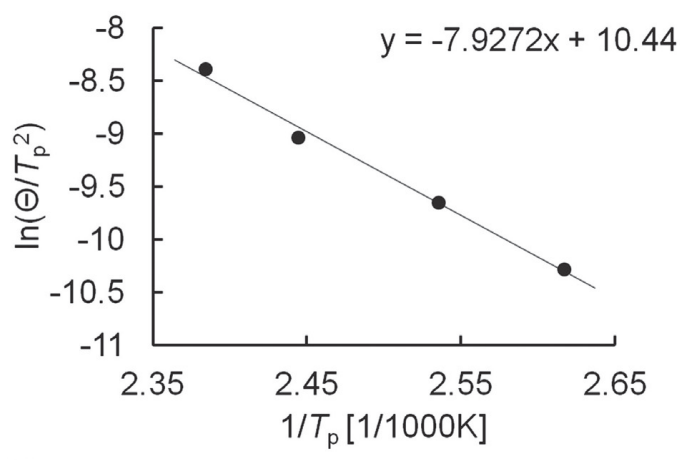

(b) Ozawa

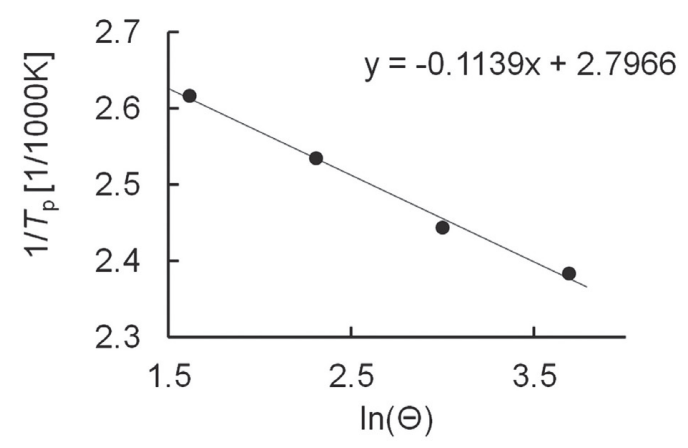

Fig. 2 Relationship between (a) $1 / T_{\mathrm{p}}$ and $\ln \left(\Theta / T_{\mathrm{p}}^{2}\right)$ or (b) $\ln \Theta$ and $1 / T_{\mathrm{p}}$ for DGPDC resin which are plotted for calculation of the activation energies.

Table 2 Activation energies of each epoxy resin calculated from Kissinger and Ozawa's equation.

\begin{tabular}{ccc}
\hline \hline Monomer & $\begin{array}{c}E_{\mathrm{A}}(\text { Kissinger }) \\
{[\mathrm{kJ} / \mathrm{mol}]}\end{array}$ & $\begin{array}{c}E_{\mathrm{A}}(\text { Ozawa }) \\
{[\mathrm{kJ} / \mathrm{mol}]}\end{array}$ \\
\hline DGPDC & 65.87 & 69.39 \\
DGIPA & 56.26 & 60.06 \\
DGEBA & 61.84 & 65.48 \\
\hline
\end{tabular}

フトがみられる.この結果は高温でより反応が進みやす いことを意味しており，このような場合でも式(2)からは 活性化エネルギーが大きいと計算される。したがって, 硬化反応が速い一方で活性化エネルギーが大きいという， 一般的には矛盾する結果が得られたものと考えられる. DGPDC 樹脂においては, 高温側で反応を加速する要素, 具体的には, Fig. 3(a)に示した PDC 環に由来する開環な どの副反応が考えられ, これが高温での反応加速に寄与 していると考えられる[15-17].「鉄粉/DGPDC 硬化樹脂薄 膜層」界面の ESCA スペクトルを示す[Fig. 3(b)]. 比較 すると, 後者のピークは明確に高結合エネルギー側にシ フトしており, 金属表面と DGPDC 樹脂硬化物との強い 相互作用を反映している. すなわち, 高温での硬化反応 においては, 金属表面の $\mathrm{M}-\mathrm{OH}$ ないし $\mathrm{M}=\mathrm{O}$ 基などの弱塩 基に対しても PDC 骨格が開環付加していることを示唆す る. それが既報した DGPDC 樹脂の極性表面への強固な 接着力[約 89MPa, 対 SUS304]の源であると考えられる. なお, DGEBA 樹脂系では Fig. 3(b)に相当するような ESCAのピークシフトは見られず, 通常の鉄表面と同等の スペクトルを与える. 同様な PDC 化合物の開環反応は比 較的強い塩基の添加によりみられ, PDC ジイソプロピル アミドに NaOEt を加えた状態での開環による鎖状化合物 の生成が in situ NMR 測定における PDC 環 3,5-位の特徴 的なプロトンシグナル消失から確認された $[18]$.

(a)

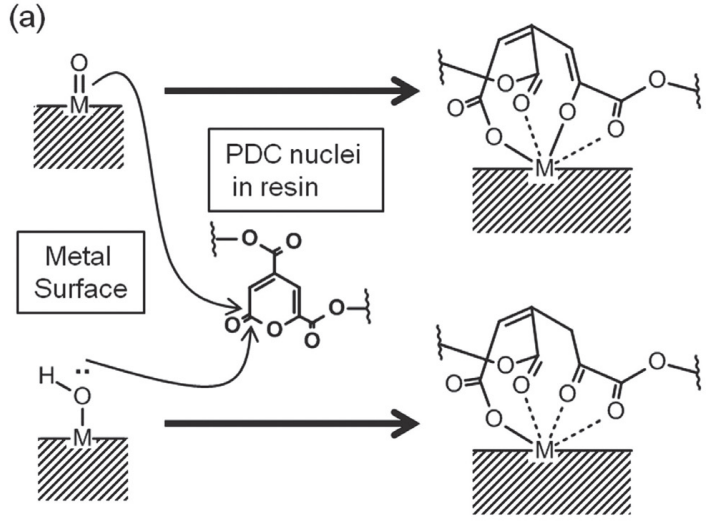

(b)

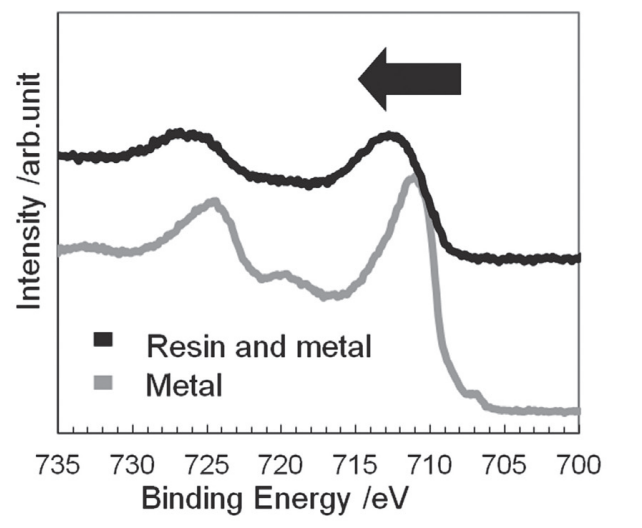

Fig. 3 Side reaction at the Metal/DGPDC resin interface. (a) Anticipated reaction mechanism. (b) $F e 2 p$ ESCA spectra at the surface of Fe powder (grey) and the interface of "Fe powder/ cured DGPDC resin" (black). 
Table 3 Initial and calculated constants for Kamal equation.

\begin{tabular}{cccccc}
\hline \hline & & \multicolumn{4}{c}{ Calculated Constants } \\
Constants & Unit & Initial Value & \multicolumn{2}{c}{ of each Epoxy Monomer } \\
& & & DGPDC & DGIPA & DGEBA \\
\hline$m$ & - & 0.342 & 1.55 & 1.04 & 0.629 \\
$n$ & - & 1.14 & 1.58 & 1.19 & 0.971 \\
$m+n$ & - & 1.48 & 3.13 & 2.23 & 1.60 \\
$A_{1}$ & $\mathrm{~s}^{-1}$ & 0.1 & $\leftarrow$ & $\leftarrow$ & $\leftarrow$ \\
$A_{2}$ & $\mathrm{~s}^{-1}$ & $1.72 \times 10^{7}$ & $\leftarrow$ & $\leftarrow$ & $\leftarrow$ \\
$E_{1} / R$ & $\mathrm{~K}$ & 19796 & $\leftarrow$ & $\leftarrow$ & $\leftarrow$ \\
$E_{2} / R$ & $\mathrm{~K}$ & 8866 & 7471 & 8020 & 8354 \\
\hline
\end{tabular}

\section{2 反応速度パラメータ評価}

通常, エポキシ樹脂の反応速度パラメータは, DSCを 用いた温度一定での時間掃引を種々の温度で行い導出す る[26-27].しかし, 今回のサンプルでは目標温度に達す る前に硬化反応が開始し，上記の実験系ではパラメータ を定量的に評価できない. そこで, 既報 [29,31-32]を参考 に昇温測定から反応速度パラメー夕を求めた。

エポキシ樹脂の反応モデルとしては, 式(3)〜 (5)で表 わされる Kamal 式がよく用いられる.

$$
\begin{aligned}
& \mathrm{d} \alpha / \mathrm{d} t=\left(K_{1}+K_{2} \alpha^{\mathrm{m}}\right) \cdot(1-\alpha)^{\mathrm{n}} \\
& K_{1}=A_{1} \exp \left(-E_{1} / R T\right) \\
& K_{2}=A_{2} \exp \left(-E_{2} / R T\right)
\end{aligned}
$$

ここで, $\alpha$ は硬化度 (反応率),$m$ および $n$ は反応次数, $K_{1}$ および $K_{2}$ は反応速度定数, $A_{1}$ および $A_{2}$ は物質固有の定 数, $E_{1}$ および $E_{2}$ は活性化エネルギーである．また， $n, K_{1}$, $A_{1}, E_{1}$ は $\mathrm{n}$ 次反応成分に, $m, K_{2}, A_{2}, E_{2}$ は自触媒的な反 応成分に，それぞれ対応している。式(3)では反応速度が 時間の微分となるため, 昇温測定から直接的に求めるこ とができない，そこで，式(3)に昇温速度 $\beta$ を導入すると， 反応速度が温度の微分となり, DSC の昇温測定の結果と の対応が可能となる $[$ 式(6)].

$$
\mathrm{d} \alpha / \mathrm{d} T=(1 / \beta) \cdot\left(K_{1}+K_{2} \alpha^{\mathrm{m}}\right) \cdot(1-\alpha)^{\mathrm{n}}
$$

Table 3 に示す初期值を基に, 式(6)から得られた理論曲線 と Microsoft ${ }^{\circledR}$ Excel に含まれるソルバー機能を用いて実験 值から得られた曲線とのフィッティング[32]を行い, 各 モノマーの反応次数, 速度定数を算出した (Table 3). 反 応初期に誘導期があるように思われるので, フィッティ ングにおいては, $\alpha \leqq 0.02$ の部分を除外して計算した.

Fig. 4 に示すように, DGEBA 樹脂に比べて DGPDC 樹
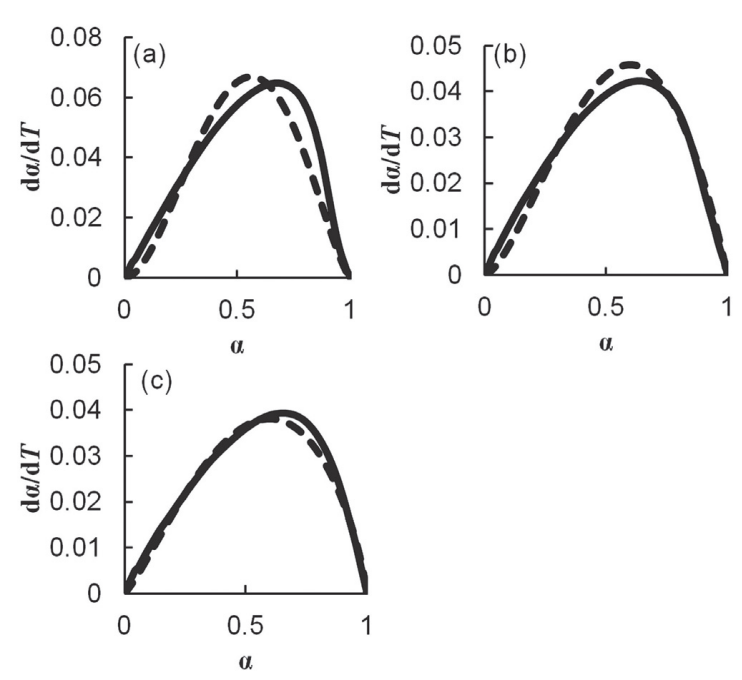

Fig. 4 Relationships between curing rate $(\alpha)$ and its temperature differentiation $(\mathrm{d} \alpha / \mathrm{d} T)$ of epoxy resins consisted of (a) DGPDC, (b) DGIPA, and (c) DGEBA at heating rate of $5^{\circ} \mathrm{C} / \mathrm{min}$. Solid and dotted lines indicate measured and calculated data, respectively.

脂では計算值と実測值の乘離がやや大きい結果になった。 通常, Kamal モデルにおける反応速度のピークは, $\alpha \leqq 0.5$ に現れると仮定されている。これは, 反応進行に従い自 触媒的に反応が加速する効果と, 反応進行に伴う基質の 減少により反応を減速する効果とが, $\alpha=0.5$ 付近でバラ ンスすると考えられることによる. また, 硬化反応が進 行すると反応物が拡散しにくくなり, 特に $\alpha \geqq 0.5$ では反 応速度低下がおきることも知られている.しかし, DGPDC 樹脂においては $\alpha=0.7$ 付近まで反応速度が上昇し続ける。 この結果は, DGPDC 樹脂系において Kamal モデルで扱う 単純なエポキシ開環反応だけでなく, 他の副反応が寄与 していることを示唆している. 本考察は Table 3 において, DGPDC 樹脂の反応次数 $m+n$ が他の樹脂に比べ, 大きい ことからも支持される. 3.1 でも述べたようにPDCの中 心骨格のピロン環がラクトン環として振る舞うので, そ の開環反応が副反応に相当すると考えられ, エポキシと 酸無水物がアニオン開環重合していく通常のエポキシ樹 脂硬化メカニズムに並行して, あるいは組み込まれて進 行すると推察している. なお, エポキシ基と環状ラクト ンがアニオン交互共重合するという類似の報告がある [33-36].

\section{3 硬化時間シミュレーション}

3.2 で求めた反応速度パラメータの妥当性を検証するた め, これらを式(6)に代入し, 縦軸を硬化度 $\alpha$, 横軸を時 間 $t$ とした硬化時間のシミュレーションを行った. 硬化 温度は, 前報 [17] と同様の $403.15 \mathrm{~K}\left(130^{\circ} \mathrm{C}\right)$ とした. Fig. 5 に示す結果より, 硬化反応は DGPDC 樹脂が一番速いと いう定性的評価となった.

今回求めたパラメータの妥当性を検証するため, 実測 值との比較を行った，計算值としては, Fig. 5 の曲線にお 


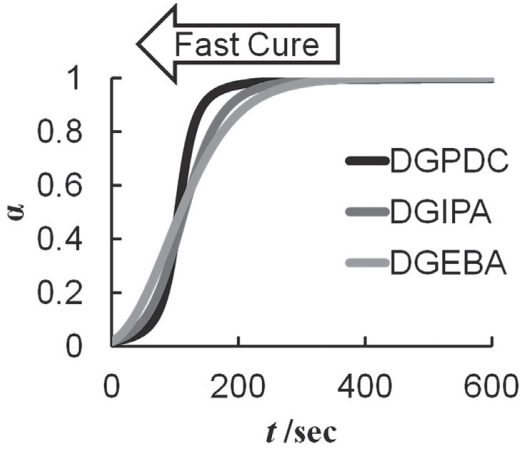

Fig. 5 Relationship between curing rate $(\alpha)$ and curing time $(t)$ calculated from Kamal equation. Calculation was started from $\alpha=0.02$ to omit the initial introduction stage.

Table 4 Curing time of each epoxy monomer.

\begin{tabular}{cccc}
\hline \hline Epoxy Monomer & DGPDC & DGIPA & DGEBA \\
\hline $\begin{array}{c}\text { Calculated } \\
\text { Curing Time }\end{array}$ & $2.5 \mathrm{~min}$ & $3.5 \mathrm{~min}$ & $4.3 \mathrm{~min}$ \\
$\begin{array}{c}\text { Experimental } \\
\text { Curing Time }\end{array}$ & $2.4 \mathrm{~min}$ & --- & $4.3 \mathrm{~min}$ \\
\hline
\end{tabular}

いて, 硬化度 $\alpha=0.02$ から反応の変化がほとんどみられな くなる $\alpha=0.95$ までの時間を「硬化時間」と定義して算出 した．硬化反応物のその場測定 FT-IRにおける「エポキ シ開環-エステル形成」の吸収帯変化の時間依存曲線から 反応終了時間を交点法により算出し $[17]$ ，実測の硬化時 間とした．Table 4 のとおり，計算值と実験值はほぼ一致 し, 反応極初期を除外して求めたパラメータの妥当性が 確認できた.

\section{4. 結 論}

リグニン由来の化合物 PDC を含むエポキシ樹脂につい て, 硬化挙動の解析を行い, 硬化反応のパラメータを定 量化した。また，ベンゼン環をもつエポキシモノマーと の比較を行ったＥSCA 測定より PDC エポキシ樹脂と金 属表面が相互作用している可能性が示唆された. DSCで の昇温測定と Kissinger, Ozawaの式を用いた解析より， DGPDC 樹脂が他のエポキシ樹脂と比べ，活性化エネル ギーが高いことがわかった。また，DSCの昇温測定を Kamal モデルに適用し, 反応速度パラメータを導出した。 その結果, DGPDC 樹脂では他の樹脂に比べて反応次数が 大きいことが分かった。エポキシ樹脂硬化時間のシミュ レーションから，DGPDC 樹脂の硬化時間がベンゼン系の エポキシ化合物を用いた二種の沉用樹脂と比較し, 一番 短い結果となり，FT-IRによる実測と一致した。

\section{謝 辞}

本研究は農林水産省委託プロジェクト研究 (H19-23)「地 域活性化のためのバイオマス利用技術の開発」, 文部科学 省科学研究費「基盤研究 $\mathrm{A}($ No. 18208027) 」「基盤研究 B (No. 11556030)」, 独立行政法人新エネルギー・産業技術総合 開発機構(NEDO) 産業技術研究助成事業(H16-18) (プロ ジェクト ID.04A19008)」，およびNEDO 委託業務等の助 成を受けて行われたものであり，深謝申し上げます。

\section{文 献}

1. A. Steinbuchel, "Biopolymers", Vol. 1 (M. Hofrichter and A. Steinbuchel, Ed.) and Vol. 3 (Y. Doi and A. Steinbuchel, Ed.), Wiley-VCH, Weinheim, (2002).

2. B. Kamm, P. R. Gruber, and M. Kamm, "Biorefineries Industrial Processes and Products", Wiley-VCH, Weinheim, (2006).

3. A. J. Ragauskas, C. K. Williams, B. H. Davison, G. Britovsek, J. Cairney, C. A. Eckert, W. J. Frederick, J. P. Hallett, D. J. Leak, C. L. Liotta, J. R. Mielenz, R. Murphy, R. Templer, and T. Tschaplinski, Science, 311, 484, (2006).

4. M. Battle, M. L. Bender, P. P. Tans, J. W. C. White, J. T. Ellis, T. Conway, and R. J. Francey, Science, 287 2467, (2000).

5. E. M. Rubin, Nature, 454, 841, (2008).

6. Y. Nishio, Adv. Polym. Sci., 205, 97, (2006).

7. E. T. H. Vink, K. R. Rábago, D. A. Glassner, and P. R. Gruber, Polym. Degrad. Stab., 80, 403, (2003).

8. S. Hirota, T. Sato, Y. Tominaga, S. Asai, and M. Sumita, Polymer, 47, 3954, (2006).

9. M. Baucher, C. Halpin, M. Petit-Conil, and W. Boerjan, Biochem. Mol. Biol., 38, 305, (2003).

10. M. P. Pandey and C. S. Kim, Chem. Eng. Technol., 34, 29, (2011).

11. P. J. Kersten, S. Dagley, J. W. Whittaker, D. M. Arciero, and J. D. Lipscomb, J. Bacteriol., 152, 1154, (1982).

12. Y. Otsuka, M. Nakamura, K. Shigehara, K. Sugimura, E. Masai, S. Ohara, and Y. Katayama, Appl. Microbiol. Biotechnol., 71, 608, (2006).

13. T. Michinobu, M. Bito, Y. Yamada, Y. Katayama, K. Noguchi, E. Masai, M. Nakamura, S. Ohara, and K. Shigehara, Bull. Chem. Soc. Jpn., 80, 2436, (2007).

14. T. Michinobu, K. Katayama, and K. Shigehara, Hyomen, 45, 239, (2007).

15. T. Michinobu, M. Hishida, M. Sato, Y. Katayama, E. Masai, M. Nakamura, Y. Otsuka, S. Ohara, and K. Shigehara, Polym. J., 40, 68, (2008). 
16. M. Hishida, K. Shikinaka, Y. Katayama, S. Kajita, E. Masai, M. Nakamura, Y. Otsuka, S. Ohara, and K. Shigehara, Polym. J., 41, 297, (2009).

17. Y. Hasegawa, K. Shikinaka, Y. Katayama, S. Kajita, E. Masai, M. Nakamura, Y. Otsuka, S. Ohara, and K. Shigehara, SEN'I GAKKAISHI, 65, 359, (2009).

18. K. Shigehara, non-published data.

19. M. E. Brown, "Introduction to thermal analysis. Techniques and applications.", Chapman and Hall, London, (1988).

20. H. A. Kissinger, Anal. Chem., 29, 1702, (1957).

21. T. Ozawa, Bull. Chem. Soc. Jpn., 38, 1881 (1965).

22. T. Ozawa, J. Therm. Anal., 2, 301, (1970).

23. A. Yusefi, P. G. Lafleur, and R. Gauvin, Polym. Compos., 18, 157, (1997).

24. M. Ghaemy, S. M. A. Nasab, and M. Barghamadi, J. Appl. Polym. Sci., 104, 3855, (2007).

25. N. Sbirrazzuoli, Y. Girault, and L. Elegant, Angew. Makromol. Chem., 211, 195, (1993).
26. A. J. Cedeno and H. Vazquez-Torres, Polym. Int., 54, 1141, (2005).

27. M. Harsch, J. Karger-Kocsis, and M. Holst, Eur. Polym. J., 43, 1168, (2007).

28. P. F. Cañamero, J. L. Fuente, and M. Fernández-García, Eur. Polym. J., 45, 2665, (2009).

29. P. Navabpour, A. Nesbitt, T. Mann, and R. J. Day, J. Appl. Polym. Sci., 104, 2054, (2007).

30. M. R. Kamal, Polym. Eng. Sci., 13, 59, (1973).

31. M. Yoshii, Polym. Eng. Sci., 48, 747, (2008).

32. M. Yoshii, Y. Mizukami, and H. Shoji, Hitachi Chemical Technical Report, 40, 13, (2003).

33. T. Takata, K. Chung, A. Tadokoro, and T. Endo, Macromolecules, 26, 6686, (1993).

34. A. Tadokoro, T. Takata, and T. Endo, Macromolecules, 26, 4400, (1993).

35. K. Uenishi, A. Sudo, and T. Endo, J. Polym. Sci. Part A : Polym. Chem., 47, 1661, (2009).

36. K. Uenishi, A. Sudo, and T. Endo, J. Polym. Sci. Part A : Polym. Chem., 47, 3662, (2009). 